\title{
Effect of electron irradiation on the electrical and optical characteristics of gallium-nitride light emitting diodes
}

\author{
${ }^{1}$ Hedzir A. S., ${ }^{1}$ Muridan N., ${ }^{2}$ Abdullah Y. and ${ }^{1}$ Hasbullah N. F. \\ ${ }^{1}$ Electrical and Computer Engineering Department, International Islamic University, \\ Kuala Lumpur, Malaysia \\ ${ }^{2}$ Malaysia Nuclear Agency, Selangor, Malaysia. e-mail: natisyahirah91@gmail.com \\ *corresponding author
}

Received: 02.03.2019

\begin{abstract}
We study the effect of electron irradiation on the electrical and optical characteristics of commercial gallium-nitride light emitting diodes in the fluence region from $10^{15}$ to $10^{17}$ electrons $/ \mathrm{cm}^{2}$. After electron irradiation, the forwardleakage current shows no significant changes, while the reverse-leakage current increases twice under the fluence $9.90 \times 10^{16}$ electrons $/ \mathrm{cm}^{2}$. This suggests the existence of radiation damage-induced traps. The irradiation reduces the capacitance and the carrier concentration, which can be attributed to deactivation of dopant atoms. Basing on electroluminescence measurements, we prove that the luminescence intensity and the red shift of peak position increase significantly with increasing dose. The peak-wavelength shift can be attributed primarily to the radiation-induced defects that cause formation of red bands and, at the same time, gradually suppress the band-edge luminescence.
\end{abstract}

Keywords: gallium nitride, light emitting diodes, current-voltage characteristics, capacitance-voltage characteristics, electroluminescence

UDC: 535.24

\section{Introduction}

Light emitting diodes (LEDs) based on gallium nitride are promising owing to such attractive properties of $\mathrm{GaN}$ as good high-energy efficiency, low power consumption and high operating temperature. Following from the previous studies, the GaN-based LEDs reveal the degradation which is two orders of magnitude lower than that of GaAs LEDs. This is attributed to wider bandgap and stronger bonding in GaN $[1,2]$. As a result, the GaN LEDs are often used as light sources in space exploration, military field and extreme industrial environments. Here a known high tolerance of GaN to the effects of radiation is also a valuable factor. The effect of electron irradiation on the characteristics of commercial GaN LEDs is interesting for better understanding of the degradation experienced by $\mathrm{GaN}$ in the extreme environments. Note that the previous studies have focused mainly on the effects of neutron and proton irradiation [3-7].

The studies of the effect of electron irradiation on the GaN-based diodes are also important for the applications linked with space exploration in the Van Allen radiation belt. Most of telecommunication satellites located at the edge of the Van Allen belt are vulnerable to the highenergy electron radiation. When a high-energy electron collides with some atom in semiconductor lattice, various defects appear that cause the performance of semiconductor electronic devices to degrade. Therefore it would be important to study the radiation hardness of commercial GaN LEDs with respect to the electron irradiation. 
In the present work we first explain the experimental details concerned with electron irradiation processing and characterization of GaN LEDs performed before and after irradiation. Then the effects of electron irradiation on the current-voltage (I-V), capacitance-voltage $(\mathrm{C}-\mathrm{V})$ and optical characteristics of the LEDs are discussed.

\section{Experimental}

The devices tested in this work are commercial blue LEDs based on GaN with plastic caps (Vishay TLHB 5400). Three electrical and optical characteristics were chosen for each dose condition. The electrical parameters were characterized by the $\mathrm{I}-\mathrm{V}$ and $\mathrm{C}-\mathrm{V}$ measurements, while the optical characterization was done using electroluminescence. The $\mathrm{C}-\mathrm{V}$ characteristics were measured at the root mean square voltage $V_{r m s}$ of $100 \mathrm{mV}$ and the frequency of $1 \mathrm{MHz}$. Pre- and postirradiation characterization of all the samples was performed in a dark setup at room temperature. The electrical experiments were performed using a Keithley 4200 Semiconductor Characterization System. The optical measurements were conducted with a HORIBA i320 electroluminescence setup. The samples were irradiated at the Malaysia Nuclear Agency, using $2 \mathrm{MeV}$ electrons.

To investigate the hardness of $\mathrm{GaN}$ against the electron irradiation, the devices were irradiated with the fluences ranged from $6.60 \times 10^{15}$ to $3.30 \times 10^{17}$ electrons $/ \mathrm{cm}^{2}$. The above irradiation region was selected since it was known that the fluence of $10^{16}$ electrons $/ \mathrm{cm}^{2}$ (the equivalent electron dose of 4 MGy) already causes severe degradation [8-11]. For each dose, at least three devices were irradiated to achieve better precision. The results shown in all the subsequent figures are representative illustrations only, because the data obtained for each fluence value and different samples is similar. Brief characteristics of our samples and fluences are given in Table 1.

Table 1. Electron-radiation fluences applied to nine identical samples of commercial GaN LED. The LED type is GaN A (Vishay TLHB5400).

\begin{tabular}{cc}
\hline Sample \# & $\begin{array}{c}\text { Electron-radiation fluence, } 10^{15} \\
\text { electrons } / \mathrm{cm}^{2}\end{array}$ \\
\hline A1 & 6.6 \\
A2 & \\
A3 & \\
A4 & 99.0 \\
A5 & \\
A6 & \\
A7 & 330.0 \\
A8 & \\
A9 & \\
\hline
\end{tabular}

\section{Results and discussion}

\subsection{I-V characteristics}

Semi-logarithmic plots of the forward- and reverse-bias I-V characteristics of the devices obtained before and after electron irradiation are presented in Fig. 1. As seen from Fig. 1a, the recombination current, which is also known as forward-leakage current, shows no significant changes at electron irradiation. Meanwhile, the reverse-leakage current changes by $30 \%$ as the fluence increases from $6.60 \times 10^{15}$ up to $9.90 \times 10^{16}$ electrons $/ \mathrm{cm}^{2}$ (see Fig. 1b). This is believed to be a result of radiation-induced defects that lead to increasing bulk density of defects and degradation $[10,12]$. Furthermore, the existence of traps located in the bandgap region can be 
associated with increasing reverse-leakage current. When irradiation happens, the traps emerge as a result of displacement of atoms. This leads to nonradiative generation-recombination of carriers through the traps located in the bandgap, thus causing increase in the reverse-leakage current [13].
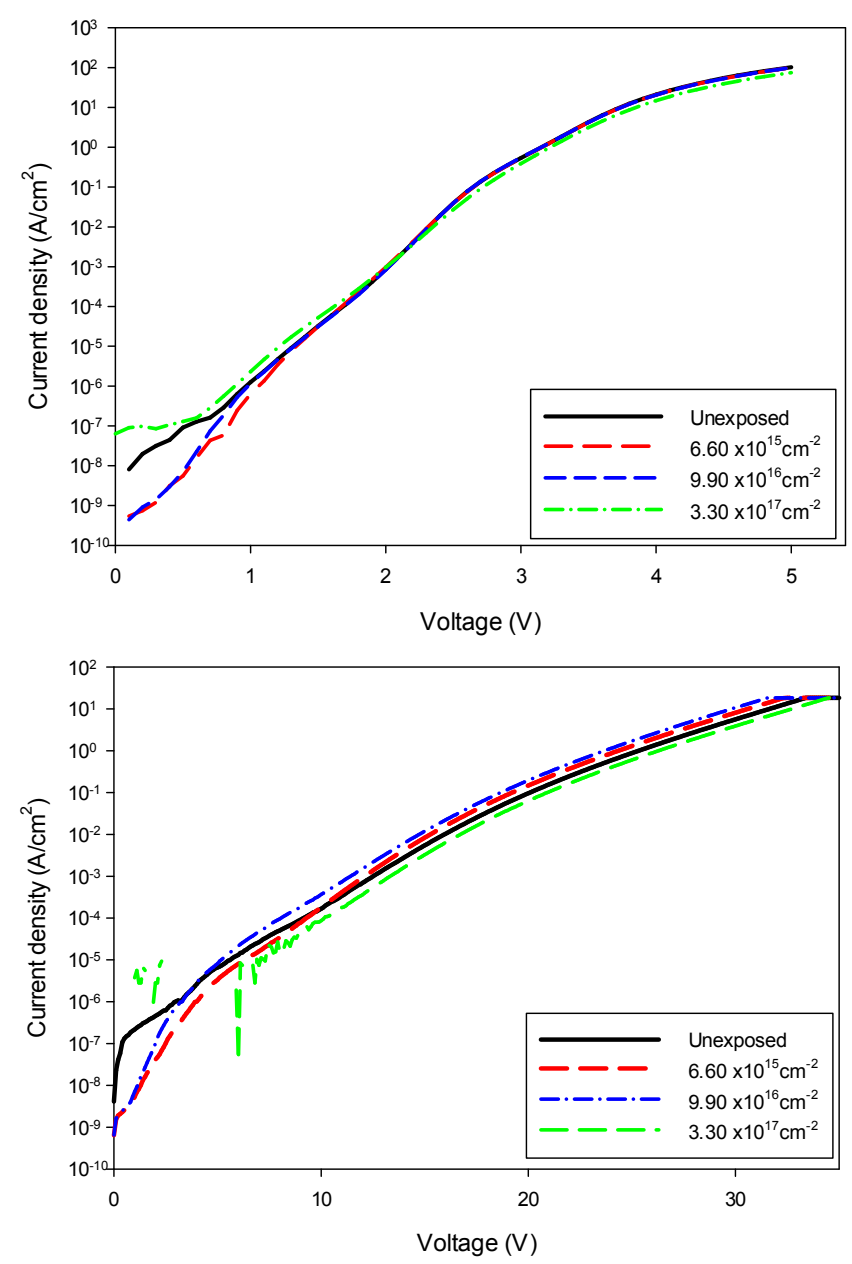

(a)

(b)

Fig. 1. Forward-bias (a) and reverse-bias (b) $I-V$ characteristics for GaN LEDs measured before and after electron irradiation. The fluences are equal to $6.60 \times 10^{15}, 9.90 \times 10^{16}$ and $3.30 \times 10^{17}$ electrons $/ \mathrm{cm}^{2}$.

However, when the devices are radiated with a larger fluence, $3.30 \times 10^{17}$ electrons $/ \mathrm{cm}^{2}$, the reverse leakage becomes slightly lower than that typical for the unexposed device (see Fig. 1b). A. Y. Polyakov et al. [10] have also reported a similar pattern for the case of high doses. This phenomenon is believed to arise due to strong compensation of $\mathrm{n}-\mathrm{GaN}$ cap layer. A corresponding schematic diagram is presented in Fig. 2.

\begin{tabular}{|c|}
\hline $\mathrm{p}-\mathrm{GaN}$ \\
\hline Depletion region \\
\hline $\mathrm{n}-\mathrm{GaN}$ cap layer \\
\hline $\mathrm{n}-\mathrm{GaN}$ \\
\hline
\end{tabular}

Fig. 2. Schematic diagram of $n-G a N$ cap layer. 


\section{2. $C-V$ characteristics}

Fig. 3a shows the $\mathrm{C}-\mathrm{V}$ characteristics measured for the samples subjected to different doses of electron irradiation. The capacitance is found to decrease by approximately $9 \%$ with increasing dose. To understand better the effect of capacitance degradation, we have derived the dependence of doping concentration $N$ on depletion width $w$ from the Poisson equation in the assumption of one-sided depletion extracted from the $\mathrm{C}-\mathrm{V}$ results. The results are displayed in Fig. $3 \mathrm{~b}$. According to the one-sided depletion hypothesis, the free carriers are assumed to be totally depleted in the depletion region. The aim of our $\mathrm{C}-\mathrm{V}$ measurements is to obtain the changes in the capacitance and the doping profiles for $\mathrm{p}-\mathrm{GaN}$ and $\mathrm{n}-\mathrm{GaN}$. In this respect, the one-sided depletion assumption can be thought of as a reasonable enough technique to compare the doping concentrations before and after irradiation.
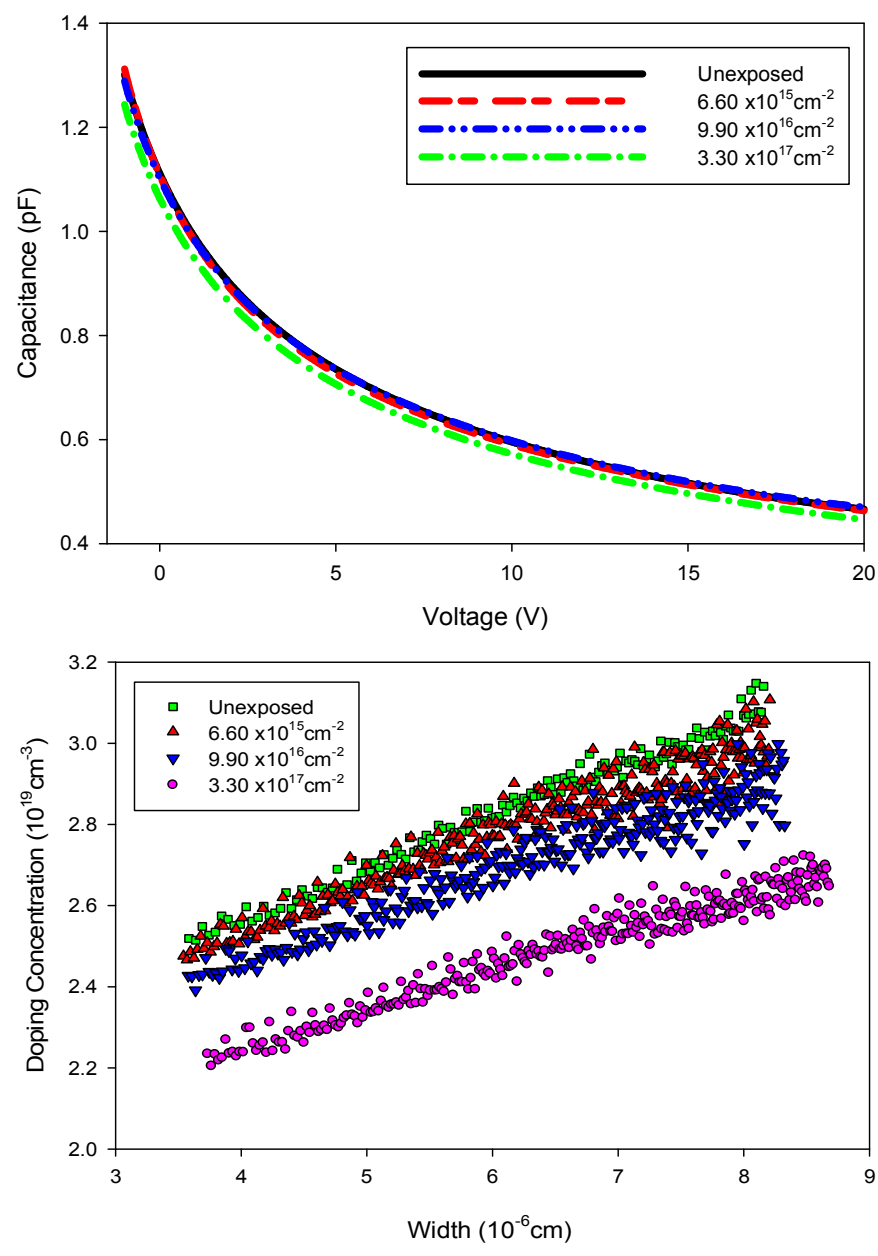

(a)

(b)

Fig. 3. C-V characteristics (a) and doping profiles (b) for the GaN LEDs obtained before and electron radiation. The fluences are equal to $6.60 \times 10^{15}, 9.90 \times 10^{16}$ and $3.30 \times 10^{17}$ electrons $/ \mathrm{cm}^{2}$.

As seen from Fig. 2, the doping concentration decreases at the fluences up to $9.90 \times 10^{16}$ electrons $/ \mathrm{cm}^{2}$. This can be associated with the carrier-removal effect which is also known as deactivation of dopant atoms $[13,14]$. When this effect takes place, the overall doping density in a sample becomes reduced. Hence, we obtain reduction in the doping density and so decrease in the 
capacitance. However, according to O. Gullu et al. [15], the reduction of the net ionized dopant concentration occurs, most likely, due to generation-recombination processes taking place inside the traps located in the bandgap. This suggests that the decrease in the doping density can be associated with the two main effects: (1) deactivation of dopant atoms and (2) generationrecombination processes induced by the traps.

\subsection{Electroluminescence characteristics}

We have found that the intensity and the peak wavelength of electroluminescence observed for all of our devices suffer the most significant changes under electron irradiation. Fig. 4a shows the loglinear plots of the electroluminescence intensity at a constant injection current before and after electron irradiation. Fig. $4 \mathrm{~b}$ illustrates the shift of the peak wavelength. Following from Fig. 4a, one can see that the overall emission intensity degrades nearly four orders of magnitude at the irradiation fluence $3.30 \times 10^{17}$ electrons $/ \mathrm{cm}^{2}$. This has to be due to radiation-induced defects that act as nonradiative recombination centres [16].

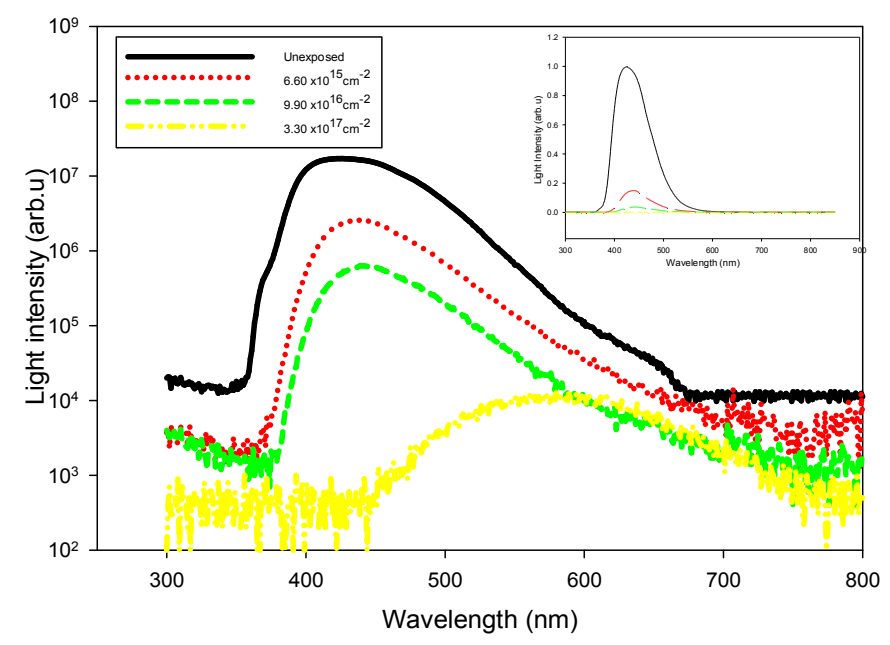

(a)

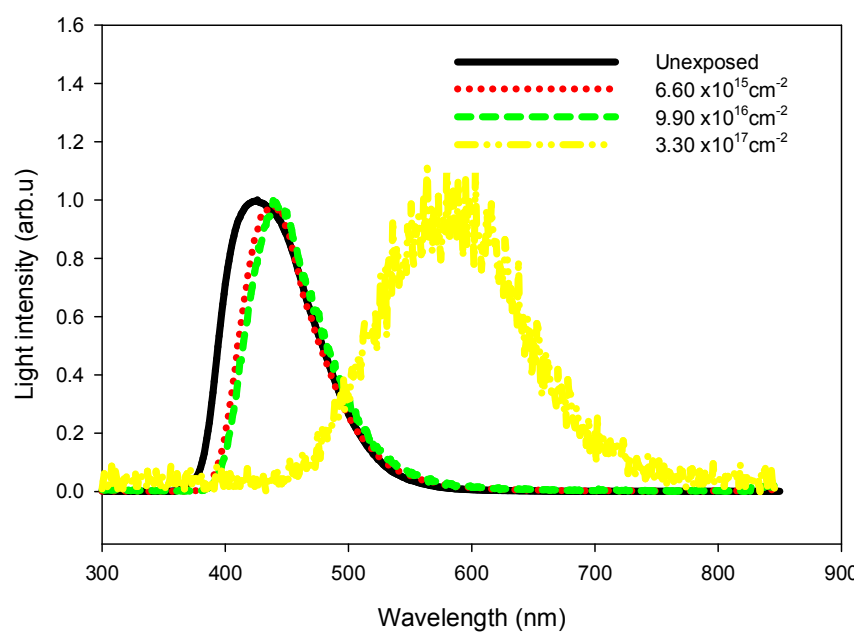

(b)

Fig. 4. (a) Logarithmic-linear plots of electroluminescence intensity and (b) normalized light intensities of GaN LEDs measured before and after electron irradiation. Inset in panel (a) shows linear-linear plot of electroluminescence intensity. The fluences are equal to $6.60 \times 10^{15}, 9.90 \times 10^{16}$ and $3.30 \times 10^{17}$ electrons $/ \mathrm{cm}^{2}$. 
As seen from Fig. 4b, the shift of the peak position increases with increasing radiation dose. The values of the red shift found at different doses are displayed in Table 2. For instance, the red shift becomes as large as $13 \mathrm{~nm}$ when the fluence increases up to $9.90 \times 10^{16}$ electrons $/ \mathrm{cm}^{2}$ (see Fig. 4b). After the electron-radiation fluence reaches the value $3.30 \times 10^{17}$ electrons $/ \mathrm{cm}^{2}$, the blue luminescence degrades drastically and a broad yellow luminescence begins to appear, with the peak wavelength located at $603 \mathrm{~nm}$. This finding can be attributed to creation of Ga vacancies in $\mathrm{GaN}$ after electron irradiation [17]. Meanwhile, the shift of the luminescence wavelength towards lower energies could be due to radiation-induced defects that cause formation of red bands and, at the same time, gradually suppress the band-edge luminescence. Further studies are needed in order to reveal the exact mechanisms responsible for the peak-wavelength shift imposed by the irradiation.

Table 2. Red shifts revealed by the commercial GaN LED at different electron-radiation fluences.

\begin{tabular}{cccc}
\hline $\begin{array}{c}\text { Electron-radiation } \\
\text { fluence, } 10^{15} \\
\text { electrons } / \mathrm{cm}^{2}\end{array}$ & $\begin{array}{c}\text { Peak wavelength } \\
\text { before irradiation, } \mathrm{nm}\end{array}$ & $\begin{array}{c}\text { Peak wavelength after } \\
\text { irradiation, } \mathrm{nm}\end{array}$ & Red shift, nm \\
\hline 6.6 & 426 & 438 & 12 \\
\hline 99.0 & 426 & 439 & 13 \\
\hline
\end{tabular}

Hence, the electron radiation has an almost negligible effect on the electrical characteristics of the commercial GaN LEDs (see Fig. 1), although it influences hard their optical characteristics (see Fig. 4). The latter characteristics experience a clear degradation with increasing dose rate. Hence, it appears that the commercial GaN LEDs are robust in their electrical characteristics with respect to the electron irradiation.

\section{Conclusion}

In the present work we have studied the effects of electron irradiation on the electrical and optical characteristics of commercial GaN LEDs. In particular, three electron-irradiation fluences, $6.60 \times 10^{15}, 9.90 \times 10^{16}$ and $3.30 \times 10^{17}$ electrons $/ \mathrm{cm}^{2}$, have been investigated. The devices irradiated with the fluence $9.90 \times 10^{16}$ electrons $/ \mathrm{cm}^{2}$ exhibit a $30 \%$ increase in the reverse-leakage current due to the appearance of traps. However, the LEDs irradiated with the fluence $10 \mathrm{MGy}$ exhibit lower leakage currents if compared to the unexposed LED. This is due to strong compensation of the nGaN cap layer taking place after irradiation. The capacitance of all our samples after electron irradiation reveals a notable reduction, which is presumably resulted from deactivation of dopant atoms. The electroluminescence emission peak shifts towards longer wavelengths with increasing fluence. The maximal red shift, $13 \mathrm{~nm}$, is observed at the electron-radiation fluence $9.90 \times 10^{16}$ electrons $/ \mathrm{cm}^{2}$, whereas a broad yellow luminescence is detected when the fluence reaches the value $3.30 \times 10^{17}$ electrons $/ \mathrm{cm}^{2}$.

By comparing the electrical and optical characteristics of the GaN LEDs, one can see that the degradation caused by electron irradiation has a significant impact on the applications associated with the optical characteristics. The electrical characteristics are more robust in this respect. Finally, the degradation parameters reported in the present study can help scientists and engineers to make well-grounded decisions when using the electronic devices based on $\mathrm{GaN}$ in the extreme environments or open space.

Ukr. J. Phys. Opt. 2019, Volume 20, Issue 3 


\section{Acknowledgment}

This research has been supported by Grant No. RAGS14-041-0104 from the Malaysia Ministry of Higher Education in accordance with the Research Acculturation Grant Scheme and also by Grant No. RIGS16-338-0502 from IIUM Research Initiative Grant Scheme (RIGS).

\section{References}

1. Pearton S J, Ren F, Patrick E, Law M E and Polyakov A Y, 2016. Review-ionizing radiation damage effects on GaN devices. ECS J. Solid State Sci. Technol. 5: Q35-Q60.

2. Ionascut-Nedelcescu A, Carlone C, Houdayer A, von Bardeleben H J, Cantin J-L and Raymond S, 2002. Radiation hardness of gallium nitride. IEEE Trans. Nucl. Sci. 49: 27332738 .

3. ChyiShiun Li and Subramanian S, 2003. Neutron irradiation effects in GaN-based blue LEDs. IEEE Trans. Nucl. Sci. 50: 1998-2002.

4. Kim H Y, Kim J, Ren F and Jang S, 2010. Effect of neutron irradiation on electrical and optical properties of InGaN/GaN light-emitting diodes. J. Vac. Sci. Technol. B. 28: 27-29.

5. Rodrigues J, Peres M, Soares M J, Lorenz K, Marques J G, Neves A J and Monteiro T, 2012. Influence of neutron irradiation and annealing on the optical properties of GaN. Phys. Stat. Solidi. C. 9: 1016-1020.

6. Lorenz K, Marques J G, Franco N, Alvesa E, Peres M, Correia M R and Monteiro T, 2008. Defect studies on fast and thermal neutron irradiated GaN. Nucl. Instrum. Meth. Phys. B. 266: 2780-2783.

7. Gaudreau F, Carlone C, Houdayer A and Khanna S M, 2001. Spectral properties of proton irradiated gallium nitride blue diodes. IEEE Trans. Nucl. Sci. 48: 1778-1784.

8. Buyanova I A, Wagner M, Chen W M, Monemar B, Lindström J L, Amano H and Aksaki I, 1999. Effect of electron irradiation on optical properties of gallium nitride. Phys. Scr. T79: $72-75$.

9. Narita S, Hitora T, Yamaguchi E, Sakemi Y, Itoh M, Yoshida H, Kasagi J and Neichi K, 2013. Effects of high-energy proton and electron irradiation on GaN Schottky diode. Nucl. Instrum. Methods Phys. A. 717: 1-4.

10. Polyakov A Y, Smirnov N B, Govorkov A V, In-Hwan Lee, Jong Hyeo Baek, Kolin N G, Boiko V M, Merkurisov D I and Pearton S J, 2008. Electron irradiation effects in GaNhnaN multiple quantum well structures. J Electrochem. Soc. 155: H31.

11. Polenta L, Fang Z-Q and Look D C, 2000. On the main irradiation-induced defect in GaN. Appl. Phys. Lett. 76: 2086-2088.

12. Ohyama H, Takakura K, Hanada M, Nagano T, Yoshino K, Nakashima T, Kuboyama S, Simoen E and Claeys C, 2010. Degradation of GaN LEDs by electron irradiation. Mater. Sci. Eng. B. 173: 57-60.

13. Ju Z G, Tan S T, Zhang Z H, Ji Y, Kyaw Z, Dikme Y, Sun X W and Demir H V, 2012. On the origin of the redshift in the emission wavelength of InGaN/GaN blue light emitting diodes grown with a higher temperature interlayer. Appl. Phys. Lett. 100: 123503.

14. Fauzi D A, Member S, Rashid N K A and Hasbullah N F. 2015. Neutron radiation effects on the electrical characteristics of InAs / GaAs quantum dot-in-a-well structures. IEEE Trans. Nucl. Sci. 62: 3324-3329.

15. Mulligan P, Qiu J, Wang J and Cao L R, 2014. Study of GaN radiation sensor after in-core neutron irradiation. IEEE Trans. Nucl. Sci. 61: 2040-2044. 
16. Kuriyama K, Kondo $\mathrm{H}$ and Okada M, 2001. A point defect complex related to the yellow luminescence in electron irradiated GaN. Solid State Commun. 119: 559-562.

17. Reshchikov M A and Morkoc H, 2006. Luminescence from defects in GaN. Phys. B Condens. Matter. 376-377: 428-431.

Hedzir A. S., Muridan N., Abdullah Y. and Hasbullah N. F. 2019. Effect of electron irradiation on the electrical and optical characteristics of gallium-nitride light emitting diodes.

Ukr.J.Phys.Opt. 20: 124 - 131. doi: 10.3116/16091833/20/3/124/2019

Анотація. Вивчено вплив опромінення електронами на електричні та оптичні характеристики комериійних галієво-нітридних світлодіодів у діапазоні потоків від $10^{15}$ до $10^{17}$ електрон/см². Після опромінення електронами прямий темновий струм не виявляє суттєвих змін, тоді як зворотний темновий струм збільшується вдвічі під впливом потоку $9,90 \times 10^{16}$ електрон/см². Це говорить про наявність пасток, спричинених дефектами. Опромінення зменшує ємність та концентраџію носії, щ⿻ можна пояснити дезактивацією атомів легуючих речовин. На основі вимірювань електролюмінесиениії показано, щзо інтенсивність люмінесценції та червоний зсув положення ї̈ піку значно збільшуються зі зростанням дози. Зсув пікової довжини хвилі можна віднести насамперед до дефектів, викликаних випромінюванням, які спричиняють появу червоних смуг $i$, водночас, поступово пригнічують крайову люмінесценцію. 